\title{
The Dutch comptoir as information centre
}

\author{
Eric Ketelaar ${ }^{1}$
}

Published online: 10 October 2018

(c) The Author(s) 2018

\begin{abstract}
While sitting in their comptoir (office), merchants in early modern Holland were able to manage their plantations in the West Indies or, nearby, their seigniories in the Netherlands because they could make use of records spanning space and time. The merchants knew that information was not only instrumental in running their own business, but was also effective on a larger scale in exercising knowledge, control, and power. The performative power of records - that they may make, and in fact do make a difference in status before and after-was used in the management at a distance. From the seventeenth century, women became involved in business. They got access to the office where records supported business outside the home, but as part of everyday life.
\end{abstract}

Keywords Business records · Social history $\cdot$ Centres of calculation · Women

Researchers of the social history of archives are, according to Markus Friedrich, challenged to answer "questions of how, why and through which agents archives and archive-related practices became integrated within the everyday life of ordinary Europeans" (2016, p. 569). Let us visit some Dutch merchants' offices to see how recordkeeping was integrated within the lives of the merchant and his family.

"A merchant should always have his hands stained with ink", wrote the Italian humanist Leon Battista Alberti in the fifteenth century (Alberti 1994, p. 218). Literacy in trade and business had already begun at an earlier date: in the fourteenth century, in north-western Europe, in Lübeck. This had led to a revolution in management: the merchant could stay at home and could send his representatives to foreign markets while maintaining continuous contact. This contact was no longer face to face, but in writing: letters, instructions and reports. In order to respond quickly to differences in prices between markets, it was vital for the flow of information to be regular and fast. That is why there was a constant flow of commercial letters between the different parties: "the nerve of commerce is

Eric Ketelaar

ketelaar@uva.nl

1 Universiteit van Amsterdam, Amsterdam, The Netherlands 
the business letter", as a scholar of Dutch trade to the Baltic wrote (Christensen 1941 , p. 179). This we see reflected in merchants' records, such as those of the sixteenth-century Dutch merchants Claes Adriaens van Adrichem and Daniel van der Meulen.

Claes Adriaens van Adrichem (1538-1607), merchant, shipowner, and burgomaster, worked from Delft, but the centre of his trade was Amsterdam (Christensen 1941; Gelderblom 2003). From his Amsterdam agent, he would receive almost daily market reports and more specifically lists of prices of various goods. Van Adrichem is in continuous contact by letter with his agent (factor) in Danzig Aper Jansz, who also works as an agent for other companies of which Adrichem is the bookkeeperin actual fact the business manager. The many letters from Danzig (Aper Jansz numbers them all, so that Van Adrichem can ascertain that the correspondence is complete, just as Van Adrichem numbers his letters to Jansz) were "enfiled", that is collected on a string, forming a lias (Wolfe and Stallybrass 2018, with illustrations). Many of the records still show a small hole, sometimes even with a part of the string attached (National Archives. Van Adrichem nr. 149). Putting loose documents on a string (Italian filza) or assembling them in bundles was standard business practice among Italian merchants and codified in Pacioli's Tractatus de computis et scripturis (1494). In the English edition of Jan Impyn's adaptation of Pacioli (1547) the merchant is advised

ye shall gather together euery moneth all suche letters as are written vnto you and bynde them vp in a bondell, and write vpon them the moneth and the yere when ye bynd them vp: And at the yeres ende ye shall bynd all the twelfe bondelles that ye had in the twelfe monethes in one bondell, and writyng likewise vpon them the date and yere, that thei maie be redy whensoeuer ye shall fortune to haue any thyng to do with them... (de Waal 1934).

The bundles were often arranged geographically and filed on liassen or in pigeonholes. Thus in the archives of Daniel van der Meulen, a merchant from Antwerp who established himself in Leiden in 1591, different series consist of letters and bills from Italy, Bremen, Antwerp, Cologne, London, etc. (Erfgoed Leiden. Daniel van der Meulen). We know how Daniel van der Meulen arranged his papers from the inventory that after his death in Leiden in 1600 was made by the notary and city clerk Jan van Hout who relied on the work of Van der Meulen's assistant Abraham Berrewijns. The latter collected and bundled the business records after his master's death. In the Van der Meulen archives (12,000 documents), preserved in the Leiden municipal archives, traces of the original way of geographical arrangement can still be recognised. Traces that have regrettably been omitted in the extensive source publication of the Van der Meulen archives (Jongbloet 1986).

Van Adrichem copied his letters to Aper Jansz and many others in his letterbook. Most of them are fair copies, but there are also some drafts. Van Adrichem wrote the letterbook himself, unlike the Italian merchants, of whom Impyn writes that they left the job to their servants. Such letterbooks were prescribed (as supplementary to the main bookkeeping registers) in merchants' manuals as late as the middle of the nineteenth century, but on the whole only for the outgoing letters (or, at the very least, 
for the most important outgoing letters). As regards the incoming letters, the way of endorsing or docketing that Impyn had already advised remained in use.

Commercial letters were information assets for merchants like Van Adrichem and Van der Meulen. They also served a larger public because information was shared on the Exchange, in the tavern, after church, in meetings and committees, etc. During the seventeenth century, Amsterdam developed into a centre of information, as Woodruff Smith and Clé Lesger have shown (Smith 1984; Lesger 2006). Information from all corners of the world was collected, exchanged and compiled, stored and analysed, new information was created and finally, information was disseminated from the city. An important information channel was the Dutch East India Company (VOC), founded in 1602.

The VOC knowledge system concerned seafaring routes, countries, people and goods. In an accumulation cycle stretching from South East Asia to Amsterdam, everything was transformed into what Bruno Latour calls "a flat surface of paper that can be archived, pinned on a wall and combined with others" (Latour 1987, p. 227). The VOC is a perfect example of what Latour has described as "centres of calculation" (Ketelaar 2008). Such a centre conditions and controls events, places and people from a distance. The centres of calculation condense the incoming primary information into secondary, which is then aggregated to new information of the third order and so forth: a never-ending "cascade of the fourth, fifth and $n$th order inscription" (Latour 1987, p. 234). Each aggregation adds value and provides new insight. Aggregation of information is characteristic for the VOC.

But the VOC was not the only centre of calculation. Each merchant maintained his own centre, linked to the one managed by the VOC. Although the VOC knowledge system was officially secret, information leaked-even flowed-from the VOC into the information systems of its directors, its shareholders and other people. The VOC set an example for Dutch merchants about the use of records to condition and control events, places and people from a distance. This knowledge could be applied to other projects. Records were equally indispensable in organising and managing large drainage projects like the Beemster polder (1612) financed by rich merchants, that created 7100 hectares of land. While sitting in their office merchants were able to manage their plantations in the West Indies or, nearby, their seigniories in the Netherlands because they could make use of records such as maps, reports, letters, rentals, surveys, tax rolls, building specifications, and financial calculations. The merchants learned from the VOC example that information was not only instrumental in running their own business, but was also effective on a larger scale in exercising knowledge, control, and power. The performative power of records - that they may make, and in fact do make a difference in status before and after-was used in the management at a distance. Of course these were businesses, but business affecting people, land and institutions. Records could accomplish something outside the office, spanning space and time. And the merchants who, in their capacity of regents, administered hospitals, old people's homes and other charitable institutions knew that these were not just establishments to be managed efficiently (Ketelaar 2014). They knew that the records they handled effected the care for patients, inmates, and orphans. Not only were the records instruments and evidence of care, but also of control and discipline. 
A business man dealing with his paperwork is a well-known theme in portraiture in the sixteenth and seventeenth centuries (Yamey 1989). However, the merchant is not often shown in his comptoir as in Jan Luyken's picture (1694) of an emblematic Dutch koopman (merchant) (Fig. 1). Originally a comptoir was a counting table (related to counter), but just like the names bureau and cabinet for a particular piece of furniture, this word came to denote a particular space: in Dutch one uses the word "kantoor" when talking about an office. In this picture the merchant is giving instructions to his clerks who are surrounded by liassen (some of them marked: England, France, Spain, etc.), registers and other records. The comptoir not only

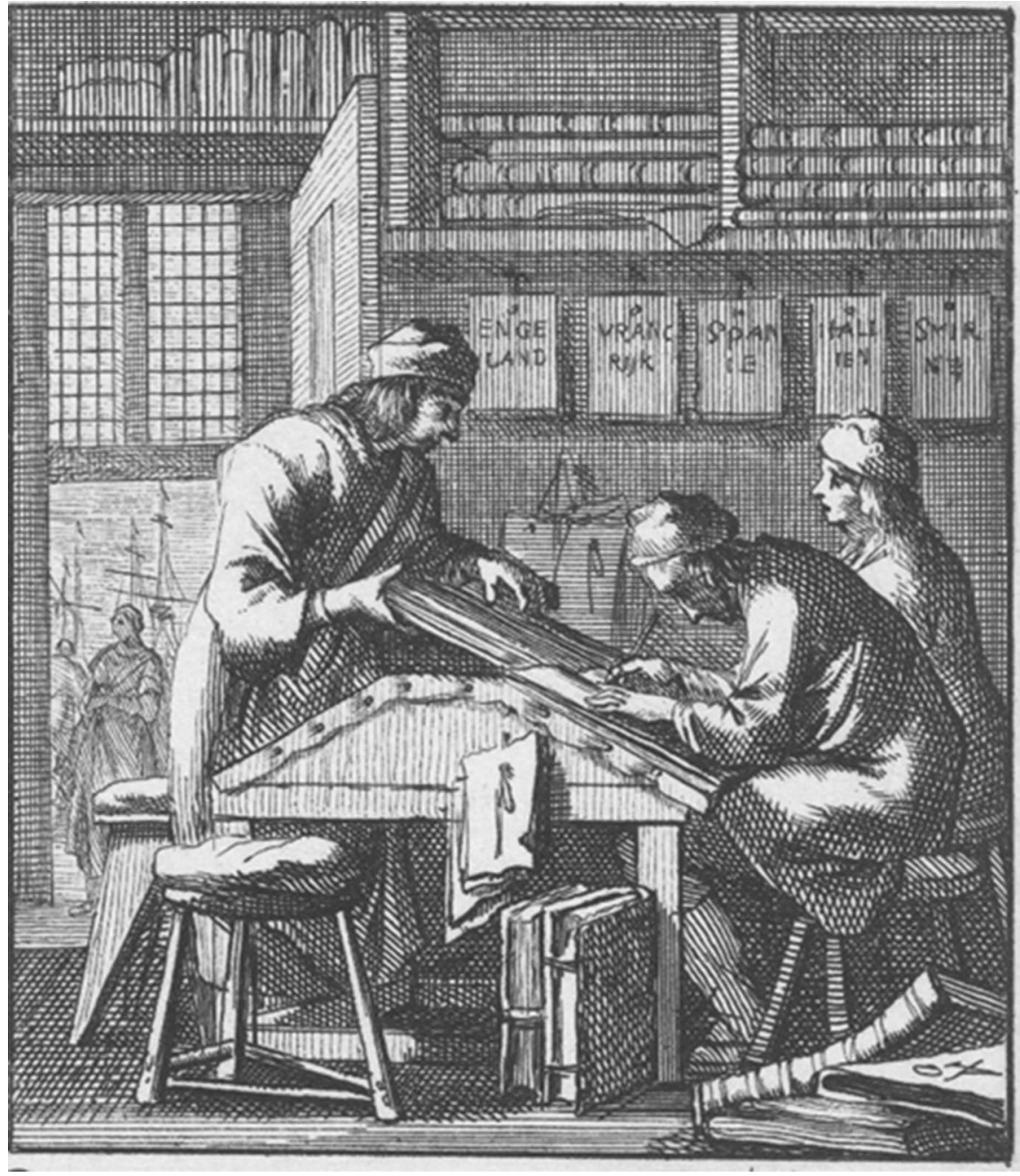

Fig. 1 Jan Luyken De koopman (The merchant) 1694, Rijksmuseum Amsterdam. Permissions to reproduce not required. https://www.rijksmuseum.nl/nl/collectie/RP-P-OB-44.553 
housed business papers, but also personal and family records, as well as documents pertaining to the public offices held by the merchant and members of his family.

As the comedy writer Gerbrand Bredero wrote mockingly in 1617 about a merchant:

He was always in his office, with his nose in the books;

His little cap on his head, in his oversleeves to prevent wear and tear of his suit

For he was always busy writing this that and the other:

He would either be drawing up a balance sheet, or counting cash,

Yes, he had so much to do that it was a miracle!

For he has in his head nooks and cupboards

And pigeon holes and drawers and dozens of files

Full of money orders, full of debentures, full of bottomry.

(Bredero 1984).

On the whole, the contents of the office were only very summarily depicted or described. The discovery of an extensive specification is therefore very rare. Such a discovery was the inventory of the estate of Johannes Hudde, made in 1705 after his death (City Archives Amsterdam. Notarissen nr. 5336B). For 21 years Hudde was burgomaster of Amsterdam, he was lord of the manor of Waveren, Botshol and Ruige Wilnis, and in his day he was also a famous mathematician (Burke 1974, pp. 76-77). He was a director of the VOC, and he was the first to try to improve VOC's reports and calculations and making them into management instruments, but to no avail (Gaastra 1989, 2002).

Hudde was portrayed by Michiel van Musscher both as a scientist and as a burgomaster of Amsterdam (van Musscher 1686). Whether the painter depicted Hudde's library or a fictitious one-as often happened in those days-is unknown. The large open book contains the charters, privileges and local laws of the city of Amsterdam. The folded letter is addressed to the burgomasters of Amsterdam, and the city seal tells us that the large document must have been issued by the city of Amsterdam.

The inventory consists of nearly a hundred pages and begins with 36 pages with the inventory of the office in his house on Singel 284. There were three cassen (cupboards), two lecterns, a table and a cupboard with pigeonholes, and shelves and even more pigeonholes on the wall. Even so papers were all over the place, not only inside the various cupboards, but also outside. Papers, letters and handwritten books were piled up, even in front of the window. Yet there was some order. Records regarding his wife Deborah Blaeuw's estate were stored in a paper cupboard. The bonds and annuities were found together in a sealed inner cupboard.

The pigeonholes served for ordering the papers: one pigeonhole held receipts and bills that had been paid, another contained the receipts regarding the Waveren estate, a third one the other property tax statements, and two more were filled with papers regarding two estates of relations by marriage. One of the shelves on the wall had pigeonholes containing papers about Waveren, but also about polders around Amsterdam. On the shelf beneath were account books and tubes containing maps. Hudde's mathematical writings - the object of Leibniz's visit in 1676-were kept in another cupboard together with other papers and manuscript books, three small bottles holding nut oil, cloves and mace, a small bible 
with gold mounting and several maps. More maps were kept in other places in the office. The second cupboard that was locked contained four little bags with money, six teacups and saucers, and papers about Hudde's public functions in town, in Holland and in the VOC.

Hudde had bequeathed all his papers (with the exception of his mathematical writings) to his cousin by marriage, town secretary Willem Dedel (City Archives Amsterdam. Notarissen nr. 4935; City Archives Amsterdam. Dedel). However, Dedel died before the Hudde estate was divided. The Hudde archive was put into temporary storage for some years and then disappeared, as did the mathematical papers. Only the documents pertaining to Hudde's public offices were saved. He had bequeathed them to Dedel under condition that any confidential document had to be transferred to the town office, the treasury or the charterkamer, the city's muniment room. Confidential papers regarding the VOC had to go to the VOC lawyer. The Dedel family kept the documents; however, in 1871, they were given to the City Archives of Amsterdam and the General State Archives (City Archives Amsterdam. Handschriften; City Archives Amsterdam. Bicker; National Archives. Hudde).

Merchants, barristers and notaries had their office at home, in a room off the front hall facing the street. This domain was part public, part private. Contemporary journals and other records show that the gentleman's office was a social space, that is: the owner would invite friends and connaisseurs to share the pleasure of reading and discussing the collections (Blaak 2009). Still, as if to mark the privilege of being invited into the office, the room was kept locked. The office was one of the six "sluitende plaatsen", or places that could be kept locked, in a gentleman's house, as described by Simon Stevin in his "Huysbou" (house building), a treatise on architecture, town planning and civil engineering (van den Heuvel 2005; de Mare 2012). Stevin, born in Bruges in 1548, emigrated in the 1580's to the protestant northern Netherlands, where he worked and taught mathematics, engineering, accounting and architecture. Stevin proposed: "It is proper for the head of a household to have six different places to which nobody else can have access, such as an office, a money chest, a silver casse (a casket, box, cupboard or chest), a jewellery casse, a casse for important letters such as contracts for houses and land and other secret letters, furthermore a library, or whatever it may be he doesn't want anyone to have access to".

According to Stevin, the mistress of the house had her own treasures: a linen chest, a clothes chest, her own jewellery chest for bracelets, rings, gold chains, pearls and the like, that she does not want anyone to have access to but herself. She had her own keys that did not match her husband's. His keys on the other hand could not open her cupboards and boxes. At least that is what Stevin writes in 1600. It is doubtful whether this gendered access to treasures was still the case a 100 years later, when commercial practices were changing and thereby the function of the comptoir - all of which affected the role of women.

Danielle van den Heuvel shows that the position of women in commerce was changing, because the work of the men changed (van den Heuvel 2007). Merchants used to trade for their own account until around 1650-1675 and they were present when a bargain was closed, thus meeting face to face their fellow traders and merchants. When, at the end of the seventeenth century, they started contracting out 
the work to commission agents they lost the need for these contacts. Instead commercial agents, brokers, firm directors or insurance agents and other specialists met their opposite numbers, while the merchant could run his business, whether small or large, from his office in his house, being only partly involved in the transaction.

Now that the home with its office had become the workplace, women also became involved. This is shown by the percentage of women among the private account holders of the Amsterdam Wisselbank (Exchange Bank) rising in the second half of the seventeenth century. In 1627, there were 1371 male accountholders and 27 female ones; in 1646 five per cent of the accountholders were women, by 1706 their number had risen to seven per cent, by 1742 this was 13 per cent, or 310 women. Most of these women were widows (74 per cent), three women were married, and the others were unmarried.

Several of these women merchants belonged to the Trip and Coymans families. Aeltje (Aletta) Adriaensdr (1589-1656), widow of Elias Trip, is number 8 on the list of the wealthiest people of the Dutch Golden Age (Zandvliet and Lesger 2006). She was painted by Rembrandt in 1639, when she was 50 years of age (Rembrandt 1639). She took over her husband's share in the joint copper trade company after his death, but she also traded under her own name. Moreover, she married off her daughters into the Coymans family, the wealthiest merchant family in Amsterdam. The eldest daughter was Sophia Trip (1614-1679) who married Johannes Coymans (1601-1657). She was the number 30 of the wealthiest people in the early modern Netherlands. When her husband died, Sophia continued the business and renamed the firm Wed. Joan Coymans and Voet (after her son in law Carel Voet). Sophia's sister Maria Trip married Balthasar Coymans, whose sister Elisabeth Coymans (1595-1653) was married to Jean Deutz (1581-1638) (Schut-Koelemij 2011, portrait p. 10). She took over her husband's business after his death, forming a partnership with her eldest son, until her own death 15 years later. Each of her still living eight children inherited 180,000 guilders.

Foreigners remarked on the active role of Dutch women in business. When in 1668 sir Joshua Child (later Governor of the East India Company) enumerated the causes of the "prodigious increase of the Netherlanders in their domestick and forreign Trade, Riches, and multitude of Shipping", one of his fifteen arguments was

The education of their Children, as well Daughters as Sons; all which, be they of never so great quality or estate, they always take care to bring up to write perfect good hands, and to have the full knowledge and use of Arithmetick and Merchants Accompts; the well understanding and practice whereof, doth strangely infuse into most that are the owners of that quality, of either Sex, not only an ability for Commerce of all kinds, but a strong aptitude, love, and delight in it; and in regard the women are as knowing therein as the men, it doth incourage their Husbands to hold on in their Trades to their dying days, knowing the capacity of their Wives to get in their Estates, and carry on their Trades after their Deaths (Child 1668).

Of course, large traders like Elisabeth Coymans employed professional bookkeepers, but it is striking that the narrative in Elizabeth's books is in the first person, even during the first few weeks after her death on 22 February 1653 (City Archives 
Amsterdam. Deutz). The books were written by her bookkeeper Antonii Martens who continued the work for Elizabeth's sons.

In Jan Luyken's picture, a woman is seen standing outside the office. Is this emblematic for the gendered management of business and the information resources in the office? I suggest that the woman is the merchant's wife who is about to enter the office, to which she had gained access, just as other wives and daughters. For her, because the office was at home, taking part in its recordkeeping operations was integrated within everyday life.

Acknowledgements Earlier versions of this paper were presented at a colloquium "Treasuries of Knowledge: Collecting and Transmitting Information in the Early Modern World", University of Cambridge, 8 April 2016 and at a conference "Information and Power in History" at the Free University in Amsterdam, 16-17 March 2017. Translations from Dutch sources are by the author.

Open Access This article is distributed under the terms of the Creative Commons Attribution 4.0 International License (http://creativecommons.org/licenses/by/4.0/), which permits unrestricted use, distribution, and reproduction in any medium, provided you give appropriate credit to the original author(s) and the source, provide a link to the Creative Commons license, and indicate if changes were made.

\section{References}

Alberti LB (1994) I libri della famiglia, ed. Romano R, Tenenti A, Furlan F. Einaudi, Torino (original work written in 1433-1440)

Blaak J (2009) Literacy in everyday life: reading and writing in early modern Dutch diaries. Brill, Leiden

Bredero GA (1984) Moortje. Martinus Nijhoff, Leiden. http://www.dbnl.org/tekst/bred001moor01_01/ bred001moor01_01_0019.php?q=\#hl1. Accessed 18 Sept 2018 (original work written in 1617)

Burke P (1974) Venice and Amsterdam. A study of seventeenth-century élites. Temple Smith, London

Child J (1668) Brief observations concerning trade and interest of money. Elizabeth Calvert and Henry Mortlock, London http://avalon.law.yale.edu/17th_century/trade.asp. Accessed 18 Sept 2018

Christensen AE (1941) Dutch trade to the Baltic about 1600. Studies in the Sound toll register and Dutch shipping records. Einar Munksgaard/Martinus Nijhoff, Copenhagen/The Hague

City Archives Amsterdam. Deutz (218) nrs. 275-276: https://archief.amsterdam/inventarissen/inventaris /234.nl.html?p=306:312:313\&t=313. Accessed 18 Sept 2018

City Archives Amsterdam. Handschriften (5059) nrs. 47-49: https://archief.amsterdam/inventarissen/ inventaris/5059.nl.html. Accessed 18 Sept 2018

City Archives Amsterdam. Notarissen (5075) nr. 5336B, pp 1547-1643

City Archives Amsterdam. Bicker (195) nr. 827

City Archives Amsterdam. Notarissen (5075) nr. 4935, pp 59-71

City Archives Amsterdam. Dedel (728) nr. 37

de Mare H (2012) Huiselijke taferelen: de veranderende rol van het beeld in de Gouden Eeuw. Vantilt, Nijmegen

de Waal P (1934) De Engelsche vertaling van Jan Ympyn's Nieuwe instructie. Economisch-historisch jaarboek 18: 1-58; repr. Selected classics in the history of bookkeeping. Series III, 2. Nihon Shoseki, Osaka 1977

Erfgoed Leiden. Daniel van der Meulen and Hester de la Faille (095) nr. 68. https://www.erfgoedleiden. nl/schatkamer/brieven-daniel-vd-meulen. Accessed 18 Sept 2018

Friedrich M (2016) Being an archivist in provincial enlightened France: the case of Pierre Camille Le Moine (1723-1800). Eur hist quart 46:568-589

Gaastra FS (1989) Bewind en beleid bij de VOC: de financiële en commerciële politiek van de bewindhebbers 1672-1702. Walburg Pers, Zutphen 
Gaastra FS (2002) Succesvol ondernemerschap, falend bestuur? Het beleid van de bewindhebbers van de VOC 1602-1795. In: Blussé L, Ooms L (eds) Kennis en compagnie: de Verenigde Oost-Indische Compagnie en de moderne wetenschap. Balans, Leiden, pp 55-70

Gelderblom O (2003) The governance of early modern trade: the case of Hans Thijs, 1556-1611. Enterpr and soc 4:606-639

Jongbloet-van Houtte G (1986) Brieven en andere bescheiden betreffende Daniël van der Meulen, 1584-1600. Martinus Nijhoff, 's-Gravenhage http://resources.huygens.knaw.nl/retroboeken/meule $\mathrm{n} / \#$ page $=2 \&$ accessor $=$ toc $\&$ view $=$ pdfPane $\&$ source $=1 \&$ size $=801$. Accessed 18 Sept 2018

Ketelaar E (2008) Exploration of the archived world: from De Vlamingh's Plate to digital realities. Arch Manuscr 36(2):13-33

Ketelaar E (2014) Accountability portrayed. Documents on regents' group portraits in the Dutch Golden Age. Arch Sci 14:69-93

Latour B (1987) Science in action. How to follow scientists and engineers through society. Harvard University Press, Cambridge

Lesger C (2006) The rise of the Amsterdam market and information exchange. Merchants, commercial expansion and change in the spatial economy of the Low Countries c. 1550-1630. Ashgate, Aldershot

Luyken J (1694) De koopman [The merchant], Rijksmuseum Amsterdam. https://www.rijksmuseum.nl/ nl/collectie/RP-P-OB-44.553. Accessed 18 Sept 2018

National Archives The Hague. Hudde (1.10.48)

National Archives The Hague. Van Adrichem (3.20.01) nr. 149

Rembrandt (1639) Portrait of Aletta Trip. Museum Boijmans Van Beuningen Rotterdam. http://collectie. boijmans.nl/nl/object/113612/Portret-van-Aletta-Adriaensdochter/Rembrandt-van-Rijn. Accessed 18 Sept 2018

Schut-Koelemij M (2011) Elisabeth Coymans, Master thesis University of Amsterdam. http://dare.uva.nl/ cgi/arno/show.cgi?fid=343544. Accessed 18 Sept 2018

Smith WD (1984) The function of commercial centers in the modernization of European capitalism: Amsterdam as an information exchange in the seventeenth century. J Econ Hist 44:985-1005

van den Heuvel C (2005) 'De huysbou'. A reconstruction of an unfinished treatise on architecture, town planning and civil engineering by Simon Stevin. Koninklijke Nederlandse Akademie van Wetenschappen, Amsterdam http://www.dwc.knaw.nl/wp-content/HSSN/2005-7-Huysbou\%20Stevin.pdf. Accessed 18 Sept 2018

van den Heuvel DWAG (2007) Women and entrepreneurship. Female traders in the Northern Netherlands, c. 1580-1815. Askant, Amsterdam

van Musscher M (1686) Portrait of Johannes Hudde, 1686, Rijksmuseum Amsterdam SK-C-528. https:// www.rijksmuseum.nl/nl/collectie/SK-C-528. Accessed 18 Sept 2018

Wolfe H, Stallybrass P (2018) The material culture of record-keeping in early modern England. In: Corens L, Peters K, Walsham A (eds) Archives and information in the early modern world. Oxford University Press, Oxford, pp 179-208

Yamey BS (1989) Art and accounting. Yale University Press, New Haven

Zandvliet K, Lesger C (2006) De 250 rijksten van de Gouden Eeuw: kapitaal, macht, familie en levensstijl. Rijksmuseum

Eric Ketelaar is Emeritus Professor at the University of Amsterdam. From 1997 to 2009, he was Professor of Archivistics in the Department of Media Studies (Archive and Information Studies) of the University of Amsterdam. As an honorary fellow of his former department, he continues his research which is concerned mainly with the social and cultural contexts of records creation and use. 